The Society for Healthcare Epidemiology of America

$\begin{array}{ll}\text { President } & \text { John M. Boyce, MD } \\ \text { President-Elect } & \text { Dale N. Gerding, MD } \\ \text { Vice President } & \text { William Jarvis, MD } \\ \text { Treasurer } & \text { Loreen A. Herwaldt, MD } \\ \text { SeCREtaRY } & \text { Larry J. Strausbaugh, MD }\end{array}$

Past President

ACADEMic Councilor

ACADEMIC COUNCILOR

Practice Councilor

Practice Councilor
Elias Abrutyn, MD

Leonard Mermel, DO, SCM

Julie L. Gerberding, MD, MPH

Donald R. Graham, MD

Barbara Wade, MD

\title{
SHEA's Project to Monitor Indicators Study Committee
}

The chair of the Project to Monitor Indicators Study Committee, Stephen Kritchevsky, PhD, reported that the EPIC study (Evaluation of Processes and Indicators in Infection Control) has entered the field and seems to be going well. A total of 69 hospitals are participating, including
16 international and 53 domestic sites. Education and training of participants was finalized in October 1998. Currently, the committee identifies data elements for the Indicator Evaluation portion of the study and compiles and processes a datacollection tool.

\section{Management of Intravenous Catheter Infections in the ICU}

The Society of Critical Medicine has invited SHEA, ACCP, ATS, and IDSA to participate in a multidisciplinary committee to develop guidelines for the management of intravenous catheter infections in the ICU. The organization is encourag- ing IDSA to fold their guidelines on therapy in catheter infections into this initiative. The SHEA board named Julie Gerberding, MD, MPH, and Len Mermel, DO, SCM, to be SHEA's official representatives to the committee.

\section{Spotted the Site?}

Web sites featuring national handwashing guidelines include the following:

1. Infection Control in the Health Care Setting Guidelines: Guidelines for the Prevention of Infectious Diseases. Author: National Health and Medical Research Council, http:// www.agps.gov.au/aboutus/infec.htm.

2. Health Protection Branch, Laboratory Centre for Disease Control.
Infection Control Guidelines-Hand Washing, Cleaning, Disinfection and Sterilization in Health Care. Contact http://www.hc-sc.gc.ca/hpb/lcdc/ dpg_e.html\#infection.

Note: The new Eurosurveillance Weekly web site has been launched. All users are required to resubscribe to the new site before they can access the news articles, archives, and other facilities. Go to http://www.eurosurv.org.

\section{Calendar}

- April 14. Hospital Infection Society, Spring Meeting, Brighton, UK. Info: http://www.his.org/ main.htm.

- April 15-16. Annual Meeting of the Society for Hospital Epidemiology of Switzerland (guest speakers: Drs. Kassirer [NEJM] and Wenzel). Info: awidmer@uhbs.ch.

- April 18-20. SHEA Ninth Annual Scientific Meeting, San Francisco, California. Info: http://www.medscape.com/shea.

- May 19-21. European Society for Pediatric Infectious Diseases 17th annual meeting, Heraklion, Crete, Greece. Info: http://www.upatras.gr/ conferences/espid99.

- May 30-June 3. ASM 99th General Meeting, Chicago, Illinois. Info: meetingsinfo@asmusa.org.

- June 6-10. Sixth Conference of the International Society of Travel Medicine, Montreal, Quebec, Canada. Contact: info@eventsintl.com.

- July 4-7. 21st International Congress of Chemotherapy, Birmingham, UK. Contact: 21sticc@gardiner-caldwell.com.

- October 29-November 2. SHEA/ESGNI Training Course, Ooghduyne, The Netherlands. Info: a.voss@mmb.azn.nl. 